it cannot be said to lend very much direct support to the theory now under discussion. ${ }^{1}$

Again, the choice of lesion in these experiments was a somewhat unhappy one. Epilepsy is a symptom which can be produced in a number of ways-its proximate cause, if there be a single one, we are not as yet in a position to formulate. At tempts in this direction usually go no further than a vigorous and often highly poetical description, in which metaphors drawn from the phenomena of electricity are liberally employed. It might have been more advantageous to have aimed at the production of less equivocal symptoms, whose pathology is less disputed-such, for example, as facial palsy.

Lastly, we cannot exclude from these experiments the possibility oi the introduction into the system of chemical poisons or even parasites, as incidental results of the operations.

But this does not by any means exhaust our stock of instances. The pages of pathology furnish us with more than one group of important facts which satisfy all the conditions of acquired characters.

Chief among these stand those numerous modifications of various organs which we regard, and rightly regard, from a clinical point of view, as part of a given disease, but which might perhaps be more correctly described as secondary ad justments made by the organism to meet certain primary morbid changes induced in different organs by the disease itself. Such, for example, is hypertrophy of the heart consequent upon valvular disease. Such hypertrophy is or is not a morbid symptom according to the point of view we happen to take. From the clinical standpoint it may be conveniently treated as part of the disease. From the biological standpoint it is an effort on the part of the organism to adjust itself to altered conditions brought about by the disease. It is certainly an acquired character, in the strict sense of the term.

An illustration will make this plain. Rheumatic fever is an hereditary disease. ${ }^{2}$ Inflammation of the valves of the heart is common in rheumatic fever, and hypertrophy of that organ often follows as a consequent of this. But who would reckon hypertrophy of the heart as forming part of a rheumatic inheritance? It is true, no doubt, that whoso is heir to a disease is heir by implication to all the biological incidents of that disease. But he is not heir to them for the same reason. The one belongs to him as the inheritor of a morbid tendency, the other as the possessor of an organism. Diabetes, again, is in some cases markedly hereditary. Secondary characters are acquired in the course of this disease also; such as hypertrophy of the bladder or stomach. But, however doomed from his cradle to diabetes a peason may be, he is not born with an hypertrophied bladder and stomach. We should think it absurd that such accommodations as these should be made before they were wanted. If, then, we are right in regarding these as really acquired characters - and it is difficult to see how we can avoid so doing-it seems that pathology has here afforded us a sort of crucial experiment. Of the morbid characters of which sundry diseases are constituted, some are inherited, some are acquiredthe one are constantly transmitted, the others, so far as we know, never are.

But no one pretends that every disease is inherited. Consider, for example, such a disease as lead-poisoning. Here, there is not, obviously, any element of heredity. That two people are not equally liable may be true enough; that pre. disposing causes exist is doubtless the case; but that does not prove an element of heredity. Predispositions may be themselves acquired, as is the case in alcoholism. In such diseases as learpoisoning, we rightly stress the importance of the environment, and minimize inherited tendencies. But such diseases will be of little use to us here, unless two conditions are complied with. The first is that they leave durable and definite lesions behind them; the second is that such lesions are not inconsistent with the procreation of children. Of such lesions the familiar " wrist drop " of lead-poisoning may be cited as a good example. It is often durable ; in not a few cases it is not cured; it is not inconsistent with the procreation of children. But there is no evidence to show that this or kindred lesions are ever trans. mitted. Facial palsy would be another instance, this malady being often of considerable duration. This group of cases constitutes another piece of negative evidence, not so import-

I For other instances of supposed transmission of morbid characters artificially produced, see Ziegler and Nauwerck. "Pathology," vol. i. pp. 39r92 ; Brown-Sśquard's operations on eyes, Mason's on the spleen.

2 "Treatise on Medicine," by Fagge and Pye-Smith. Third edition, vol. ii. $\mathrm{p} 69$

$$
\text { NO. I } 187 \text {, vOL. 46] }
$$

ant as the last, because these cases are rarer, but still not unimportant.

It can hardly be disputed that these characters are acquired in the sense under discussion. There must have been frequent opportunities of transmission, but we have no evidence of anything of the kind.

The general conclusion we have arrived at in this paper is that pathology, so far from offering any support to the hypothesis of the transmission of acquired characters, pronounces against it. We have seen that it is possible to bring up a mass of evidence, which seems at first sight to favour that hypothesis. On further consideration, however, it becomes clear that only a small portion of that evidence can be allowed to "rank."

A considerable number of facts must be rejected, because though there can be no doubt that the morbid characters here present are both acquired and transmitted, they are not acquired in the sense under discussion - that is, by the somatic cells exclusively- but by the entire organism.

A considerable number of facts, again, meet with a like rejection, because there is no question that here certain morbid characters are transmitted, yet even supposing them to have been acquired, it does not appear that precisely what was acquired is transmitted, but something broader and more general.

A considerable number of facts remain, which may be allowed to "rank" as genuine instances of acquired characters. These, if the hypothesis be correct, should be transmitted. But of such transmission we find little or no trace.

If we begin with scars and mutilations, even if the facts are not all on one side, the balance of evidence is decidedly against the hypothesis. If we appeal to the results of experimental research, the question is more open; but if the hypothesis does not encounter quite so decided an opposition in this quarter, it can scarcely be said to derive much support there.

If we pass into the main region of pathology, we have to use some circumspection in looking about for instances which shall be genuine examples of acquired characters. That such instances really exist it has been our endeavour to show, notably in those secondary characters which organisms acquire by way of accommodating themselves to the effects produced by disease. So far from being rare or recondite, these constitute a group of familiar and well-ascertained facts. If transmission bas not occurred, it cannot be for want of opportunity-there must have been scores of such opportunities. That it has not occurred, constitutes a piece of very important evidence against the hypothesis under discussion. HENRY J. TYLDEN.

\section{A TRIP TO QUEENSLAND IN SEARCH OF} CERA TODUS. ${ }^{1}$

MY main object in going to Queensland was to procure, if possible, the eggs of Ceratodus and the creature itself; secondly, I wanted to collect earthworms; and, thirdly, to see the country. In my main object I was quite unsuccessful, for the simple reason that this year Ceratodus did not lay its eggs till late on in November-two full months later than the time recorded by the only observer who had up till then procured them. University work forced me to return, not by any means empty-handed, but without the one thing which had tempted me to go north.

To save time, and avoid unpleasantness also, I went by train. It is a long weary ride across New South Wales, especially in warm weather. Unfortunately I left Sydney by the northern mail on Friday evening. There were very few carriages, and some of what there were were "engaged" for legislators who travelled home free and in ease whilst we who paid for our journey were huddled and crowded together. This discreditable state of affairs seems to be cotzimon at the close of each week during the sitting of Parliament in Sydney.

The journey north leads by the side of the Hawkesbury River, and after passing across the well-known bridge the train skirts the shores of what appears to be a succession of lakes. In reality, the winding river, shut in by wooded hills, expands every now and then into sheets of water, each of which in the gathering darkness seemed to be a little lake. About eleven o'clock you find yourself apparently running along through the streets of Newcastle, and stretching out eastwards see the long quays and

I Paper read by Prof. W. Baldwin Spencer, before the Field Naturalists Club at Victoria, on March I4. Reprinted from the Victorian Naturalist for June and July. 
open water leading out to the sea. The whole is brilliant with numberless electric lights, though you have an idea that in daylight coal dust would be a little too prominent. As it is, how. ever, Newcastle is associated in one's mind with a series of flashing and twinkling lights prettily reflected in the water and with a very second-rate refreshment-room. Afer Newcastle you settle yourself down as comfortably as possible for a run northwards of 400 miles, through the night and greater part of the next day, to the Queensland border. You seem to get gradually more and more out of the world until at five o'clock next afternoon the train pulls up at the border station. By that time our number of passengers has been reduced to four. After looking about, a minute train, which at first sight you take for a toy, is descried at the end of the platform. Further searching shows a very narrow gauge line streaking away through the limestone hills northwards into Queensland. The original name of this border station was Wallangarra, but unfortunately this is now being changed to Jennings. It is a pity to lose the old native names and to substitute for them such ugly ones. One would have thought that a more effective plan of perpetuating the memory of legislators might have been devised.

Small though the raiiway is, it is very comfortable and well managed, and all officials uniformly courteous. The carriages are like the insides of omnibuses, with a broad seat all round the windows. On express trains the last car is always for smokers, and has a little balcony on which you can sit out in the open air right at the end of the train, and hence shielded from wind and dust. This is a most excellent arrangement. From Wallangarra the train runs to Warwick, and then, across the uplands forming the Darling Downs with their wonderfully rich dark-red soil, on to Toowoomba. Here the line turns nearly due east and begins to climb gradually to the top of the Dividing Range close to the eastern escarpment of which Toowoomba lies. Suddenly you turn a corner, the upland country ends abruptly, and the train zig-zags rapidly down the face of the lofty escarpment which rises directly from the flat coastal district. The sun was setting just as we reached the crest, and in the brief twilight we had magnificent glimpses of the distant plains with the abrupt hill sides and deep gorges in the foreground. Close upon midnight Brisbane is reached.

A slight difficulty arose in Brisbane with regard to my smal amount of collecting material, but on learning that it was simply intended for scientific purposes, the Customs officials at once courteously saved me all trouble by allowing it to enter free of duty. In fact my experience in Queensland was that I met with the greatest courtesy from all officials, and the greatest kindness from such friends and strangers as it was my good fortune to be brought into contact with--an experience common, I believe, to all visitors to the Northern colony.

From Brisbane the line is now continued through Maryborough on to Bundaberg at the mouth of the Burnett River.

About seventy-five miles north of Brisbane the vegetation changes almost suddenly, and the line runs across a belt of country, perhaps twenty miles wide, of a semi-tropical description. To this we will return presently; suffice it to say at presen that the traveller finds himself suddenly surrounded by palms and pines and fig trees, and sees all the tree trunks covered with epiphytic ferns-with great masses especially of staghorn and bird-nest ferns, and with orchids from which hang down long clusters of yellow blossom.

This belt of vegetation stops as suddenly as it began some few miles south of Gympie--a well-known gold-mining town, which lies by the side of the Mary River, and where I had been told that Ceratodus was to be had in abundance. Here I determined to stay, and began at once to make inquiries. To my disappointment I found that no one at the hotel knew anything about the animal, but I wandered forth in quest of information. The river itself was dirty with the washings from the mines, and looked anything but promising; however, I made for some miserable huts on the outskirts occupied by Chinese, and after a little trouble found a fisherman amongst them. This individual was decidedly apathetic, but after some time said that he might or might not be able to catch me a few. Wandering along by the river I began to feel rather as if I were searching for a needle in a haystack. However, I learnt that the fish certainly were to be caught, though some few miles away, but that there was no chance whatever of getting assistance from any blacks, simply because there were not any in the neighbourhood, and at that time I thought their assistance indispensable. It was late in the afternoon and I wandered on by the river searching for planarians and earthworms. Amongst the former I secured two specimens of a beautiful new species, to which Dr. Dendy has given the name of Geoplana regina, and also specimens of the almost cosmopolitan form, Bipalium kezvense, and of Geoplana cerulea, a form common in New South Wales, rare in Victoria, and very abundant indeed in Queensland. This was, I believe, the first time on which land planarians had been collected in Queensland-not that there was any difficulty in finding them, but that no one had taken the trouble to look before. Amongst earthworms, I collected for the first time for myself a true perichæte-that is, one in which the little setæ, or bristles, form a complete circle round each segment of the body. In all our Victorian forms, without exception, there is a break in the middorsal and ventral lines where the setæ are absent. True perichætes do not appear to come further south than the north of New South Wales. Under the logs also were specimens of a common Queensland worm, Cryptodrilus purpureus; of a new species of perichæte worm, $P$. gympiana; together with three species of frogs-Pseudophryne bibronii, $P$. australis, and Limnodynastes tasmaniensis.

During the evening I had the opportunity of talking to one or two who were well acquainted with the country, and was strongly advised to go on without delay to the Burnett River. I determined that this would be the wisest course to adopt, and accordingly packed up next morning, and after an hour or two's stroll round Gympie, during which I did a large amount of log. rolling with but scanty success, owing to the extreme dryness of the country, once more took train northwards towards Maryborough. I spent the night at a little wayside inn, where considerable surprise was evinced at my putting in an appearance; however, a wandering lascar turned up, so that I was more or less kept in countenance, and together we had tea in what was presumably a combination kitchen and scullery. During two or three hours' collecting I met with nothing but gum trees, endless ants and scorpions, a few stray specimens of Geoplana corulea, and one or two lizards and frogs. I somehow had the idea that north of Brisbane everything would be at least semi-tropical, and could not at first help feeling disappointed to find myself, except in the small district mentioned before, surrounded by little else but gum trees, without a trace of a palm or of anything which looked at all tropical. Eastern Gippsland was really richer in vegetation and more varied in form of animal life than the part of Queensland in which 1 spent most of my time. In fact, so far as my experience yet goes, Gippsland, as a general collecting ground, would be very hard to beat.

Early in the morning I started in a mixed train along a branch line leading inland for some fifty miles, till it stopped apparently nowhere in special, and not far from a fine mountainous bluff. The station is called Biggenden, and here we found coaches waiting for us. A Queensland coachdriver is a most marvellous man, both in the way in which he accepts with almost pleasure any amount of luggage, and in the way in which he stows it all on board. From Biggenden came a hot ride of about forty miles across uninteresting country. The only township we passed was a small place known as "The Shamrock," not far from the goldfield of Paradise. After changing horses we started off again, seeing nothing but gum trees and a few emus and kangaroos. Arnong the gums were what are locally known as blood gums, whose light-coloured trunks are covered with reddish blotches, due to the exhalation of kino; woollybutts, -which for perhaps ten feet above the ground have the trunk somewhat like that of a stringybark, and above this are quite smooth and whitish ; and a form of gum called brigalow. This grows in clumps, and differs from all the others in having its foliage comparatively dense, so that it affords a good deal of shade. The cattle congregate in the shade, and these dark patches give a curious and characteristic appearance to the landscape. Every now and then we came across a few birds, known as squat pigeons. These have the habit of squatting on the ground when approached, and, being of a brownish colour, are hard to see. Sometimes they can be knocked over by the whip of an experienced driver.

Late in the afternoon we mounted a slight ridge and came down through a gap into the wide Burnett Valley. On either side of this rise low hills, and through the middle flows the river with a broad channel, occupied chiefly-except during the flood season-by long, broad stretches of sand. A short ride brought us to Gayndah, a long, straggling township on the river banks, and here I took up my quarters in the comfortable

NO. I I 87 , VOL. 46] 
Club Hotel. At one time Gayndah was the centre of a wool. producing district, and bears evident signs of having seen a better day.

Intent on meeting with Ceratodus, I made my way to $\mathrm{Mr}$. Thomas Illidge, the postmaster of Gayndah, to whom I had been recommended, and I gladly take this opportunity of expressing my thanks to him, not only for the valuable help and information which he gave me, but for many acts of kin lness which added greatly to the pleasure of my stay in Gayndah. may here also express my thanks to my friends, Dr. Cole and Messrs. Frank and Virgil Connelly, from whom-though a complete stranger-I received most valuable help. If a naturalist wishes to meet with genuine kindness and every possible assistance, I can warmly recommend Gayndah to him.

One of the first things I learnt was that Dr. Siemen, of the University of Jena, had recently come to the Burnett district for the purpose of securing the eggs of Ceratodus, and the various development stages of Platypus and Echidna; and not only this, but that he had secured the services of the available blacks. - I must confess to a feeling of something like chagrin at having come so far to meet with, apparently, no cbance of success in what was my main object.

After sleeping over my preliminary disappointment, I determined on carrying out the only plan possible, which was to obtain one or two boys accustomed to the river, and, with their help, to at any rate get Ceratodus, and, if possible; the eggs. It was now well on in September-the time at which Mr. Caldwell had found that the animal had laid eggs-so there was still hope that I might secure them. Perhaps it may be well here to state briefly the special interest which attaches to this particular form Ceratodus. As you all know, there are two groups of animals-the fishes and the amphibia - of which the first live in water, and breathe by means of gills, whilst the second either spend, as the newts do, their whole life in water, breathing by means of gills, or else, like the frogs, spend the early part of their life in water, breathing by gills, and then come out of the water and breathe by lungs just as reptiles and mammals do.

Now there is a very small group of animals known as the Dipnoi, which are, we may say, intermediate between the fishe and the amphibia. They are neither so lowly developed as the fishes, nor so highly developed as the amphibia-in fact, they may almost be described as "missing links" which still exist, and show us the way in which air-breathing were evolved from water-breathing animals. If we simply went by their external appearance we should class them amongst fishes, which they closely resemble in many respects. Now, fishes have what is known as a swim-bladder, which is merely a long hollow process developed from the œesophagus. This serves, probably, mainly as a float, and not at all for respiratory purposes; but in the small group, Dipnoi, of which Ceratodus is one, this same swim. bladder becomes modified to act as a lung. Not only this, but, whereas in fishes the impure blood which is carried from the body to the heart passes to the gills, is purified there and then goes straight to the body, in the Dipnoi part of the blood goes from the heart to the lung, and then is carried back again to a chamber in the heart specially developed for its reception. In fact, in the Dipnoi we can see some of the earliest stages in the evolution of important organs of the body as we now find them in all animals above fishes.

At the present time only three examples of the Dipnoi are known to exist in the world-one form, Lepidosiren, lives only in the Amazon; another, Protopterus, is only found in tropical Africa; and the third, Ceratodus, occurs only in the Burnett and Mary Kivers, in Queensland. In past times, however, Ceratodus lived in other parts, such as Europe, as its fossil remains testify ; and in Australia Prof. Tate has recorded the presence of its teeth in the strata of the Lake Eyre basin. In fact, Ceratodus is one of those rare forms of which fossil remains were found and named before the living form was discovered.

The habits of Protopterus have been studied, and it is stated that during seasons of drought it makes a cocoon of mud for itself, and breathes by means of its lung. On account of this habit, these forms have often been called mud and lung fishes.

My main aim, then, was to find the eggs of the Ceratodus. From Mr. Caldwell's published notes, which are only too brief, I knew that it deposited them much like some amphibians, such as the Axolotl, do, on weeds, and that he had found them in September.

$$
\text { No. I } 197 \text {, vor. } 46]
$$

To return now to Gayndah. I purchased a tent and provisions, and having hired two boys accustomed to the river, started away to camp out some few miles up the Burnett. The country was very dry and sandy, with all the creeks empty of water. The outcropping rocks are granitic, with basalt capping the hills around, and the disintegration of the granite appears to give rise to a vast amount of sand. Along the river itself there is an alternation of large sandbanks, where the stream is shallow, and of long deep pools with great granite masses. The banks are bordered by bottle-brush trees (Callistemon), which at that time were crimson with flowers, and alive with thickheads. Leaving my stores to find their way to an appointed spot, I kept by the river bank on the look-out for weeds, for without these it was hopeless to set to work. After a short halt at a station close to Mt. Debatable, where the sociable wasp (Polistes ferrugineus) was busy making its nest in the verandah, I walked on until we were some six or seven miles out of Gayndah but there was not a trace of weed in the river. Close in to Gayndah, there was a small quantity, but where we expected to find a good supply there was none at all, owing apparently to heavy floods which in the last wet season had swept down the river. Accordingly we turned back and pitched our camp not far from Gayndah. It was evening by the time we were settled down, and too dark to see the eggs, so we lit a fire and fished. It was a lovely moonlight night and the coolness was delightful after the heat of the day. The river is full of fish, and we caught sand eels and mud eels, jew-fish, perch, and bream, but not a single Ceratodus-or, as they call it locally, salmon. Turtles kept rising to the surface and showing their black heads above the water, and every now and then when we sat still we could recognize a Platypus. In the morning I set to work to search over the weed. One of my boys stripped and went into the river for it, whilst I sat half in and half out of the water looking carefully over each piece. In the hot blazing sun this was not enjoyable, and after some hours' work, and not the slightest sign of an egy, and when the small patch of weed was pretty well exhausted, I sat down to think, and questioned my boys closely as to where there was more weed. A little way on the other side of Gayndah they told me there was a backwater usually full of weed. Why they had not told me of this before I could not imagine, and the remarks made probably conveyed this idea to them. However, we were close to the end of this weed, and as we had to get to some more, I sent one boy into Gayndah to procure help in removing our camp, for which, fortunately, I had made previous arrangements In the afternoon I finally exhausted the weed and myself with no result, and for a change set to work to turn over a few logs. Amongst planarians, Geoplana corulea and variegata; amongst earthworms, Crypto. drilus purpureus; amongst frogs, Limnodynastes tasmaniensis and Hyperolia marmorata; and amongst lizards, species of Pygopus, Hinulia, and Egernia, and a small nammal, a species of Antechinus, rewarded my efforts, but everything was too dry, though the season was early, for anything very much in the nature of worms. Along the river banks endies; numbers of the beautiful butterfly Danais erippus attracted my attention. It was feeding on the plant (Lanthana) along with which it has been introduced. In the river itself was to be seen the curious water lizard Physignathus lesueurii, of which we caught a small specimen, and also the frog Hyla lesueurii, whilst the Callistemon trees contained plenty of a little green species of Hyla which the boys used as bait for fishing, and which appears to be new to science. I also caught this same frog on window panes at night in Gayndah, where, like a moth, it goes to the light. As the evening came on the mullet began to jump. They feed especially on a filamentous alga which grows in the water, and contains numerous. crustaceans, especially a prawn-like form, for the sake of which they eat the alga. 'The latter is used as bait for them. At night we caught a large mud eel, five feet long, which we eagerly drew into land, thinking it to be a salmon. I tried sugaring the trees, but it was of no use, not even a single ant put in its appearance, and thus ended another day of hard work and disappointment.

In the morning I had my boys up by 4 a.m., and before six we were out of camp, and by nine o'clock had our tent pitched by the side of a back water on the other side of Gayndah. This contained plenty of weed, and here I spent some days. We procured a long pole, with three prongs at the end, to pull the weed up with. We used to get a large bucketful at a time, and then go over it piece by piece. This process had to be conducted under a hot sun, and the result was that my arms became swollen to ahout double their natural size - so much, indeed, that I could 
not sleep with anything like comfort, since the slightest pressure woke me up. The final result was that I did not see the slightest trace of any Ceratodus eggs, though, had they been there, there is no doubt but that we should have found them. I then sent one of my boys down the river for some miles to see if there were any more weeds, but there were none to be seen. Just at this juncture I heard of some hlacks, but on trying to secure them found that they were anticipating a "muster" on one of the neighbouring stations, and were not to be procured. Seeing no prospect of getting what I wanted, and being none the better for my exposure to the sun, I went into Gayndah.

Here I may, perhaps, say something as to some conclusions I had come to with regard to the habits of Ceratodus. With the exception of the brief account given by $\mathrm{Mr}$. Caldwell as to the laying of its eggs on weed, and the curious amphibian-like embryos, we know little about the natural history of the animal. As before said, it is confined to two Queensland rivers-the Mary and the Burnett, and my experience is limited to the latter. Firstly, with regard to the animal's name. The Dipnoi have two popular names--" Jung fishes" and "mud fishes"- the latter given to them because, in the case of Protopterus, the animal may live for a part of the year in mud. The Ceratodus is not known locally by either of these names; it is, however, sometimes called the "barramundi" and sometimes the "salmon." The first of these is, however, really that of a true osseous fish (Osteoglossum leichardtii), which lives chiefly in the Dawson and Fitzroy Rivers, further north than the Burnett. The second is a fanciful name, given on account of the very pink-coloured flesh of the animal. Beyond this there is no resemblance whatever between the real and the so-called Burnett "salmon." Mr. Saville Kent, in his report on fishes to the Queen land Government, states that Ceratodus is a valuable food fish. This is a curious mistake. Its flesh is very oily, coarse, and disagreeable, and it is but rarely eaten, and then only by Chinese and those who can afford nothing betier. There is thus, I am thankful to feel, not much fear that so interesting an animal will become rapidly exterminated.

Now, as to its method of life. Ceratodus is a big fish, and may reach the length of six feet, and even more. I believe the largest ever caught weighed eighty-seven pounds. It is always to be met with in the deep pools, and not in the shallow waters, and it is important to notice that these pools are many of them of con. siderable extent, some more than a mile long. In the hottest summer they contain a good supply of water, and thus, though occasionally a Ceratodus may, of course, find its way into a shallow pool which gets dried up, normally no such thing happens, and the animal passes its whole life in water. The usual idea is that the lung is of service to the animal, as in the case of Protopterus, when the waters practically dry up. I very much doubt if Ceratodus ever makes for itself a mud cocoon, as Protopterus does. It may possibly, but very rarely, bury itself in mud, but the fishermen with whom I spoke, and who were perfectly well acquainted with the animal, knew nothing of its ever doing this. On the contrary, I fancy that the lung is of at least as great service to the beast during the wet weather as during the dry season-and probably even of greater.

Normally, then, we may say that Ceratodus never leaves the water. If by any chance it gets out of the water it is perfectly helpless. You may put one close to the edge and there it lies passively. Its weak limbs are quite incapable of sustaining the weight of the body. Nor can it live out of the water, unless kept c mstantly damp, for more than a very few hours-not, indeed, so long as the jew-fish from the same river. In the water, however, it constantly uses its lung. Sitting by the stream when all is quiet in the evening, you can hear a diminutive kind of spouting going on, the animal at intervals rising to the surface and expiring and inspiring air much as a minute whale might do. Out of the water, too, it does not open and shut its gill flaps like an ordinary fish, but they remain tightly shut, and the animal opens and closes its mouth, to all appearances breathing like one of the higher forms.

If we consider the environment of the Ceratodus we shall see that there are two special and constantly recurring conditions under which a lung would be useful to it.

In the wet season the tributary creeks, dry in summer, become transformed into roaring torrents, and when once you have seen the great sandbanks along the river bed and the dry sandy country through which the creeks pass, you can easily recognize

No. I I 87 , VOL. 46] what a vast quantity of sand must be brought down during the course often of a very few days, and how thick the water must become with fine particles. On the other hand, during the hot season there suddenly grow with enormous rapidity great quantities of water weeds. The river is then at its lowest and the decaying vegetable matter will often render the water foul. Under either of these conditions you can see that the possession of an organ enabling the animal to remain in its natural element and yet breathe air directly will be of great advantage to it. It is the shallower pools especially which become chocked with weeds, and since normally the Ceratodus lives in the deeper pools, in which is the purer water, it i., I think, very probable that the flood season, when the water is disagreeably full of sand and mud, is the time when the lung is of greatest service.

In Gayndah I learned that Dr. Siemen was camped out some forty miles up country, where the Auburn and Bowen Rivers jnin the Burnett, close to one another. Accordinuly I made up my mind to go up the river, both to see him and to search for weed. The difficulty was how to get there. However, I met with a friend in the person of Mr. Bailey, proprietor of the Queensland Hotel, who, at considerable inconvenience to himself, promised to see me through the difficulty; and, taking one of my boys with me, we left Gayndah early one morning, before 4 a.m.

The country was extremely dry and sandy, with poor gum trees, and every now and then a patch of brigalow. By IO. 30 we reached a wayside accommodation house, and then in the heat of the day we started off along a most miserable track across country as utterly uninteresting and monotonous as can well be imagined. We had two good dogs with us, and the only, break in the monotony was when they put up a big "iguana." Most were much too quick for them, but one they got hold of, and it $n$ as wonderful to see how they stuck to him without getting within reach of his mouth. When all was over I slung him over a dead trunk, to get his head on the way back. However, when we came back he was not perfectly fresh, and was left behind. By 4 o'clock we had crossed the Bowen River and pitched our camp about a mile beyond. Then I walked on to Dr. Siemen's camp. My adient was announced by the yelping of sundry mongrels, the property of a small camp of blacks. On these animals I kept a sharp look-out. Dr. Siemen I found living in comparative luxury; and from him I received a most cordial welcome. We spent the evening most pleasantly talking over matters of common scientific interest. Three of his blacks came in with a few Echidnas. I learnt from him that he had been no more successful than myself in procuring Ceratodus eggs - that, in fact, they had not begun to spawn yet. Unlike myself, however, he was able to stay there until they did spawn, and most generously offered to procure certain material for me. There was a small amount of weed in the river but not a trace of an exg. On cutting open the body of a "salmon" I found the spawn inside, looking very similar, indeed, to that of a frog, each separate egg being black in colour at one pole. It was evidently not yet quite ripe for laying. The season when Mr. Caldwell got his eggs in September seems to have been an exceptional one as regards the temperature and amount of weed in the river. There had been no big flood for some time previously to his visit, so that the river was full of weed and everything was favourable for the depositing of spawn. 'This season, as luck would have it, the warm weather started rather late and the weeds had been largely washed away by heavy floods, the river at the end of September being comparatively high. I think it safe to say that, granted the presence of eggs, they could be got by "whites" just as well as by "blacks." Any collector going at the right time and not frightened of tiring and tedious work could get them for himself now that the manner of spawning has once been ascertained. Each egg, surrounded by a little gelatinous capsule, is laid on weed, but I think, from what I heard with regard to $\mathrm{Mr}$. Caldwell's metheds, that he found it necessary to spend a very considerable time in the neighbourhood of the river whilst the embryos were slowly developing, as they were not easily and safely carried about. The next day Dr. Siemen and I spent together with, I trust, mutual enjoyment-at all events, to myself it was one of the pleasantest days I spent in Queensland. I did a small amount of collecting, but it was far too dry and sandy to get anything in the way of worms. Down by the river I came across a black woman and pickaninny fishing, but they were frightened when I spoke to them, and fled. There were large numbers of Danais erippus, and of a beautiful species of Acrea with transparent wings. Late in the afternoon I at- 
tempted, but with not very great success, to photograph some blacks. One especially, named Frank, had his back scored with cicatrices in regular pattern. I spent the evening till I I o'clock with Dr. Siemen, and said good-bye to him, wishing sincerely that he might be successful in his endeavours to secure what we were both in search of, and what it was perfectly evident that $I$ myself could not obtain.

I may here say that Dr. Siemen had with him the best of the blacks who were with Mr. Caldwell, and who secured for the latter the eggs of Ceratodus. These blacks were fine and powerfully-built fellows; but here, as everywhere else, rum and disease are rapidly lessening their numbers.

On the way back our dogs started many big lizards, and it was amusing to see one of them hanging on to the tail of a large Cyclodus gigas, whose head and body were hidden in the hollow of a log. Jew lizards we met, as well as species of Hinulia and Liolepisma. We camped by the Burnett, some twenty miles out of Gayndah, and spent the evening fishing in a little backwater. There are two kinds of turtle in the river, the longnecked (Chebodina longicollis) and the short-necked (Chelymis macquariensis), and sometimes one is surprised at pulling out a turtle instead of a fish. Next day we made our way back into Gayndah, passing by large patches of grass trees in full flower, with swarms of the little black native bees hovering around them. Just as we were passing through a mob of travelling cattle our dogs started two kangaroo rats (Bettongia, sp.). There was a general scattering as the little animals, with the dogs in full chase, ran through the mob. After a short run one was caught, which had in its pouch a single small young one not more than $\mathrm{I} \frac{1}{2}$ inch long.

I stayed a few days in Gayndah, hoping to make a collection of earthworms, which up till then there had been very little chance of collecting. The name of the township will be well known to Australian etymologists, since it was here that $\mathrm{Mr}$. Masters made a very fine collection; he was fortunate enough to have almost a year in the district, and thus secured forms at all seasons. About a mile behind the township is a large stretch of scrub, where I spent a considerable time, often accompanied by one or other of my friends-Messrs. Illidge, Cole, and Connelly -to whom $I$ am indebted for help in the laborious task of digging out worms from dry ground. My favourite place was a large patch centering in a big bottle tree, Sterculia quadrifida (?). Here was an open space, lightly timbered with small trees of Melia azedarach, the light green foliage of which formed a strong contrast to the sombre foliage of the dense scrub all around. Besides eucalyptus and bottle trees, the scrub was made up of such trees and shrubs as Geijera muelleri and salicifolia, which were covered with small yellowish flowers, Leptospermum lanigerum, Bursaria spinosa, Nephelium (sp.), Hovea longipes, Solanum stelligerum, \&c. I am indebted to the Baron von Mueller for his kindness in giving me the names of plants, to Mr. C. French for names of Coleoptera, to Mr. A. H. S. Lucas for names of amphibia and lizards. From the open spaces alleys lead away into the recesses of the scrub, and along these numbers of the beautiful Danais erippus, Papilio erectheus, and Acrasea (sp.) kept flying to and fro. Of birds, probably because I was not specially on the look-out for them, I saw very few.

The two most numerous forms of life were ants and millipedes. The moment you put anything which could serve as food for them on the ground, the former appeared as if by magic. Several times they spoilt butterflies just while I put them down on the ground and made a paper bag for them. They always bit off first the little knob at the end of the antenna. White ants of course abounded, and in the tree trunks were swarms of native bees. There were not as many logs to turn over as could have been wished for, and the ground also was rather too dry and sandy.

We began by digging around the base of the big bottle tree, and, after digging some time, came across some large worms, about two feet in length. These differ in habit from any others I have collected. The burrow runs down for perhaps two feet, and then opens into a small chamber. The head end of the worm lies usually a short distance up the burrow, whilst the greater part of its length is twisted into a knotted coil, and lies in the chamber which may also contain one or two smaller, immature forms, evidently the young of the larger ones. Under and in rotten logs you often meet with a shortish, stout worm, perhaps six or eight inches in length, which, at first sight, differs very much from the long one. Its body is stiff, and the surface comparatively dry, whilst the other is four or five times its length, the body soft and the surface always very slimy. The short one I met with all along the Burnett River, at Gympie and in the palm district between this and Brisbane, whilst Mr. D. Le Souef collected it at Toowoomba. It is the Cryptodrilus purpurezes of Michaelsen, and, much though the two differ in habits and appearance, the long one is at most a variety of the short, typical form. I only got it in this one spot. In the scrub were some four new species of the same genus, and three new species of a genus (Didymogaster) of which previously only one species had been described from New South Wales, by Mr. Fletcher. Of the typical Victorian genus, Megascolides, to which our large Gippsland earthworm belongs, I did not find any example in Gayndah, but the Perichætes were fairly well represented.

Most of the earthworms were secured under fallen logs and in rotten trunks of the bottle tree. In times of drought the latter are cut down, and, containing a great amount of moisture, are eaten readily by cattle.

The season was too early for beetles, but amongst others I secured specimens in the family Carabidæ of Carenum deauratum and bonelli, Eutoma (sp.), Philoscaphus mastersii, and Homa. losoma hercules; and, in the Paussidæ, of Arthropterus (sp.). One species of the genus Leptops, in the Curculionidæ, simply swarmed on the bark of the bottle trees and some of the upturned logs in the more open parts were alive with the little red form, Lemodes coccinea.

A short time before leaving for Queensland I had been struck with the presence of curious laterally-placed segmental openings in a very large millipede from $\mathrm{Fiji}_{\mathrm{i}}$, which $\mathrm{Mr}$. French had kindly forwarded to me. In the Gayndah scrub-where smaller, but still large, millipedes abounded-I was interested to find the mean!ng of these openings. Each one is connected with a gland, and, when irritated, the animal passes out a few drops of a most obnoxious finid, of a red-brown colour, the function of which must be protective. Whilst on this subject, I may mention that one morning, when Mr. Frank Connelly and myself were digging for worms, we accidentally cut in two a cockroach. From between the segments in its back it poured forth a milky white fluid, possessing an odour so execrable and pungent that it drove us from the spot.

Under logs we found, also, of land planarians, Geoplana cerulea and variegata, and amongst Vertebrata, the frogs Limnodynastes tasmaniensis, which was common everywhere, and Hyperolia marmorata. Of lizards, we secured species of Phyllodactylus, Pygopus, Grammatophora, Hinulia, Liolepisma, and Egernia. Snakes were rare, only the genera Morelia, Furina, and Hoplocephalus being represented. Whilst in the scrub I did not see a single marsupial.

On the road from Biggenden to Gayndah I had been struck with the appearance of two small hillocks capped with basalt. The country all round was thinly wooded with nothing but gum trees, but just the tops of these two hillocks were rich with vegetation, though each was at most fifty yards in width. Dr. Cole, Mr. Illidge, and myself drove out to see if there were anything worth collecting. Unfortunately, since I had passed along the country had been fired and everything was as dry and parched as it well could be. However, just the very cap of the hills still formed a strong contrast to the surrounding country, and here we found growing - though nowhere else, apparently, except in these two very limited areas-Damara robusta, the Queensland Kauri, Cupania xylocarpa, Micromelum pubescens, Carissa brownii, Citriobatus (sp.), and amongst ferns a rich growth of Polypodium (sp.), and Adriantum (sp.). Animal life was almost absent. We disturbed three wallabies, but except these and a few millipedes and scorpions and endless ants, there was nothing to be seen.

My time was passing by rapidly, and though I would much have liked a few more days in the Gayndah scrub, it was a choice between this and two or three days in the palm district between Gympie and Brisbane. Regretfully I left Gayndah, and taking the coach back to Biggenden, found myself in the evening in Maryborough. In the morning I had about two hours to wander about. Close to the town were camped some blacks. It was curiors to note how they had adapted themselves to their environment. They had made their "humpies" out of old sheets of corrugated iron. A semi-clothed native lying down in the shelter of a mia-mia made of English corrugated iron formed as incongruous a mixture as could well be imagined. Early in

$$
\text { No. I I } 87 \text {, VOL. } 46]
$$


the afternoon $I$ left the train at Cooran and took up my quarters in a delightful little wayside inn surrounded by ferns. On going up to the house I detected at once the genuine Lancashire dialect, and knew that the owner bailed from within ten miles of Manchester. I was accordingly made welcome, and wandered out to do a little collecting before evening came on I found myself just on the northern border of the palm scrub which ran in a broad belt of about twenty miles width across the country from east to west, inland from the sea coast. The country was fairly hilly with a few isolated peaks standing out clearly. I was just at the base of one of these-Cooran-and to the south lay two more-Cooroora and Pimparan. South from these again the ridges increased in height, and then the country fell away into the slightly undulating plains which stretched eastwards towards Bribie Island and southwards to Brisbane. Some remarkable peaks, called the Glass Mountains, mark the southern end of the hilly district.

So far as animals are concerned, I was much disappointed with this palm scrub, but equally delighted with the richness of the vegetation.

Commencing first near to Cooran, I followed back the line and "log-rolled," finding a few worms and four land planarians (Rhynchodemus obscurus), a small, dark-coloured form, and Geoplana carulea and variegata, together with specimens of a very small new white species, to which Dr. Dendy has given the name of G. minor. After long searching I came across Peripatzes leuckartiz, very dark purple in colour and evidently similar to the typical form and without the curious diamond-shaped markings characteristic of the Victorian form. Though searching hard, I only found nine specimens altogether, and all these close to Cooran. Most of my time was spent in this scrub at different parts, and usually in company with George Martin, the son of my Lancasbire friends, who helped me very considerably in collecting. The scrub was very thick with vines and prickly lawyers and barristers and supplejack, making progress tedious, and there were comparatively few logs on the ground. What delighted me most were the ferns. The trunks of the pines and gums were often covered over with them and with orchids. High up were enormous clumps of the bird-nest fern (Asplenium nidus), and larger ones of the staghorn (Acrostichum alcicorne). Some of the latter measured fully twelve feet through, and from thene hung down lovely pendant fronds of smaller ferns, especially of Polypodium tenellum, which is locally known as the feather fern. On the ground grew various species of Davallia, Adiantum, Pteris, Doodia, Aspidium. Polypodium, \&c. Perhaps the most beautiful of all were the large and delicate fronds of Adiantum formosum. There were apparently three forms of palms - species of Ptychosperma, Livistona, and Kentia. The latter is very common, and usually known as the walking-stick palm. In the scrub were great pine trees, and under the bark stripped off from these, and lying about in large slabs, I expected to find any number of worms and insects, but was much disappointed. Millipedes and scorpions were there, and two large forms of Jand shells; but scarcely an insect to be seen, and not a planarian or peripatus. I got a few new species of earthworms, of which, again, the commonest form was Cryptodrilus purpureus; and in rotten $\log s$, which, unfortunately, wrere few in number, were large forms of cockroaches. The earthworms formed the best part of my collection here, and comprised representatives of five genera--Perichæta, Megascolides (one species, the only one found), Cryptodrilus, Perissogaster, and Acanthodrilus. The latter is only recorded, as yet, from Northern Australia, where there are two species, and is characteristic of New Zealand. Perissogaster is peculiarly Australian and has only three species yet known. My specimens were obtained by digging on the banks of a creek at Cooran and were whitish in colour and about $I$ to $I \frac{1}{2}$ feet in length. The boys use them for fishing, quite unaware of their scientific value.

In Queensland, as in Victoria, I could very rarely, indeed, find traces of casts made by worms or of leaves dragged down into the burrows, and it would appear that here, as in Africa, the ants are of more use than the worms as agents in turning over the soil. Under the bark and logs were a few frogsPseudophyrne bibronii and coriacea, Crinia signifera, and a female specimen of Cryptotis brevis. In certain spots there were great numbers of trap-door spiders. Some of the tubes, which led for about 2.4 inches down into the ground, were an inch in diameter. The top of the tube, with its semi-circular trap.door, projects slightly above the surface.
One of the most striking features of the scrub were the epiphytic orchids, of which, owing to its size and large pendant masses of yellow-brown flowers, Cymbidium canaliculatum was the most noticeable. In parts the ground was crimson with the fallen berries of a species of Eugenia : we cut one down about sixty feet high, laden with fruit, which has a tart taste, and from its colour and size has caused the tree to be known as the native cherry. Another Eugenia has a large purple fruit, and is hence known as the native plum. High up, some fifty feet above ground, we saw hanging down clusters of light brown fruit. Luckily there was a hanging vine close at hand, and up this George Martin went like a monkey. The fruit belonged to the tree Dysoxylon rufum, and each was covered over with in numerable minute stiff hairs, which pierced the skin in hundreds. Other plants we noticed were the wistaria, which here grows wild, Dracena angustifolia, and one which Baron von Mueller has marked as rare-Rhipogonum elseyanum. Two dangerous ones are common, one with large bright green leaves and succulent sheathing stalks, which is locally known as the "Congey Boy"-this is eaten greedily by the native turkeys, but has the effect of making a man's tongue swell to an enormous extent; the other is the stinging tree, Urtica gigas - the sting of this is extremely painful, and seems to prove fatal to horses, driving them rapidly frantic.

Close by the base of Mount Cooroora, a beautiful specimen of Macrozamia denisoni in fruit was growing, and on Mount Cooran the rock on the western side was completely overgrown with staghorn and bird-nest ferns and with an orchid, Dendrobium (sp.), with beautiful clusters of delicate white floners, amongst which trailed Kennedya rubicunda, its bright red blossoms contrasting strongly with the pure white of the orchids.

My last day I spent at the Glass Mountains-curious conelike basaltic structures rising abruptly from almost flat country. The day was oppressively hot, making it no small exertion to even turn over a log, and as the sun went down a heavy storm came up, and from the train I caught my last glimpses of this delightful district lit up by almost incessant flashes of brilliant lightning

\section{SCIENTIFIC SERIALS}

The American Fournal of Science, July. - The change of heat conductivity on passing isothermally from solid to liquid, by C. Barus. The method employed was a modification of Weber's, who placed a thin, wide, plane-parallel plate or layer of the substance to be examined between and in close contact with two thick plates of copper. The system was first heated so as to be at a given temperature throughout. It was then suddenly and permanently cooled at the lower surface, and the time-rate at which heat travelled from the top plate to the bottom plate, through the intervening layer, was measured by a thermo-couple. From these data the absolute thermal conductivity of the layer may be computed, the constants of the system being known. In the experiments discussed, the liquid was thymol, which can be kept either solid or liquid between $0^{\circ}$ and $50^{\circ} \mathrm{C}$. This was heated above its melting point, and introduced through a central hole in the upper plate; it was then allowed to cool down until undercooled. The temperature was regulated by enclosing the whole apparatus in a sheet-iron jacket, through which water was kept circulating. The lower plate could be cooled by flushing it with water from below. The difference of temperature of the plates was measured by means of a copper german-silver couple. The liquid was solidified by introducing a crystal through the central hole. The results obtained gave for the absolute conductivity of thymol in $\mathrm{g} / \mathrm{cs}$ :

Solid thymol at $\mathbf{1} 2^{\circ}, k=359 \times 10-{ }^{6}$ Liquid thymol at $13^{\circ}, k=313 \times 10^{6}$

The thermometric conductivity was found to be-

For solid thymol at $12^{\circ},=1077 \times 10^{-6}$

For liquid thymol at $13^{\circ},=691 \times 10^{-6}$

-On polybasite and tennantite from the Mollie Gibson mine in Aspen, Colorado: by S. L. Penfield and Stanley H. Pearce. Large quantities of polybasite or "brittle silver" have been mined nearly free from gangue, assaying from 10,000 to 16,000 ounces of silver to the ton. Tennantite, arsenical tetrahedrite, or "grey copper," was found in smaller quantities, containing about fourteen ounces of silver. The rich ore occurs between a

NO. I I 87 , VOL. 46] 